\title{
Study of Pretreatment and Enzymatic Hydrolysis on Microcrystalline Cellulose and HVS A4 Paper in Pressurized $\mathrm{CO}_{2}$ Media
}

\author{
Ian Eka Pramudita ${ }^{1}$, Marcella Lauditta Noviana ${ }^{1} \&$ Henky Muljana ${ }^{1}$ \\ ${ }^{1}$ Department of Chemical Engineering, ParahyanganCatholic University, Indonesia \\ Correspondence: Ian Eka Pramudita, Department of Chemical Engineering, ParahyanganCatholic University, \\ Bandung 40141, Indonesia. E-mail: hmuljana@yahoo.com
}

Received: May 4, 2015

Accepted: June 5, 2015

Online Published: June 30, 2015

doi:10.5539/mas.v9n7p16

URL: http://dx.doi.org/10.5539/mas.v9n7p16

\begin{abstract}
The aim of this work is to investigate the potential used of pressurized $\mathrm{CO}_{2}$ in the pre-treatment and the enzymatic hydrolysis of waste HVS A4 paperto produce a monomeric sugars (C5 and C6 sugars) which is a precursor for bioethanol production. Prior to the utilization of waste HVS A4 paper, the microcrystalline cellulose and HVS A4 paper were first used in the experiments as model compound in order to gain better insights of the process.

The experiment consists of two main parts which are the preliminary experimentsto determine the best pretreatment conditionsbetween two selected pressure values $(80$ and $100 \mathrm{bar})$ at a fixed temperature $\left(\mathrm{T}=75^{\circ} \mathrm{C}\right)$ and the enzymatic hydrolysis experiments. In the latter, the microcrystalline and HVS A4 paper were hydrolyzed at different pressures (100 bar, $125 \mathrm{bar}$, and $150 \mathrm{bar})$ and at different cellulase intakes (1\% (v/v), 3\% (v/v), and 5\% $(\mathrm{v} / \mathrm{v}))$ with a fixed temperature $\left(50^{\circ} \mathrm{C}\right)$. The hydrolyzed products were analyzed with a High Performance Liquid Chromatography (HPLC) to quantify the monomeric sugars and to determine the presence of the side products (furfural, HMF and levulinic acid).

Within the experimental range, a maximum glucose concentration of $7602.35 \mathrm{ppm}$ and $4560.79 \mathrm{ppm}$ are obtained for microcrystalline and HVS A4 paper, respectively. In addition, there are no furfural, HMF and levulinic acid detected in the products This study shows a potential used of pressurized $\mathrm{CO}_{2}$ in the pretreatment and enzymatic hydrolysis of the model compound and gives a better insight for further application.
\end{abstract}

Keywords: pretreatment, enzymatic hydrolysis, biomass, waste paper, pressurized $\mathrm{CO}_{2}$

\section{Introduction}

Energy is one of the basic human needs, andthe amount of energy resources such as fosil fuels begin to deminished (BPS). Therefore, people start to findan alternative for the fossil fuels. One potential alternative is fuel derived from biomass in the form of bio-ethanol. Compared to fossil fuels, bio-ethanol has two advantages, which are clean and renewable. Bioethanol is usually synthesized from the microbial fermentation of sugars obtained from various crops such as wheat, sugar cane, beets etc (M. Wang, J. W.; J. X Tan). However, the large scale production of bioethanol from these materials is limited due to the competition with food application (M. Wang, J. W.; J. X Tan). Another potential resource for bioethanol production is from lignocellulosicmaterial such as paper and itswaste (Ana Luiza F. S).

In the past few years, the export of papers from Indonesia has significantly increase, indicating a rise in a worldwide paper consumption. The increase in paper consumption, however, results in an increase to the production of its waste. Unfortunately, for most industrial processes, waste papers are treated as factory wastes by which, no further processes are taken to refine it. The amount of waste paper in Indonesiareached 3.6 million tons in 2008 and contributes for nearly $10 \%$ of the amount of waste in Indonesia (Anjani, A). As a lignocellulosic material, waste paper contains $87 \%$ of cellulose, which can be further hydrolized to produce a monomeric sugars (C5 and C6 sugars) which is a precursor for bioethanol production (Howard, R. L), (Franceschin, G). Therefore, if waste paper can be converted into bio-ethanol, its value surely increases (Sutjiadi, H. A).

There are many hydrolysis processes that have been developed. Among others, the acid catalyzed hydrolysis is commonly used. However, not only monomeric sugars, the acid process produce furfural, hydroxymethyl furfural (HMF) and organic acids as side products which can inhibit further fermentation processes. In order to 
increase the selectivity, theenzymatic hydrolysis process may be carried out. However, the main drawback from the enzymatic process is a long reaction time as compared with the conventional acid catalyzed processes. Therefore, there is a strong incentive to find an alternative to improve the reactivity of the enzymatic processes. As a potential alternative, a pressurized $\mathrm{CO}_{2}$ is used as a solvent in the process.

Up till now, there are already several papers reported the application of $\mathrm{CO}_{2}$ as the solvent in enzymatic hydrolysis of various lignocellulosic materials such as wheat straw, corn cobs and sugar cane (Taherzadeh, M. J), (Santos, A. L. F). These papers show a higher reactivity of the enzymatic processes due to the higher accessibilty of the enzyme inside the cellulose matrices in the presence of $\mathrm{CO}_{2}$. Although, there are already several papers reported the potential application of $\mathrm{CO}_{2}$ in the enzymatic hydrolysis of lignocellulosuc materials, however, to the best of our knowledge, there are no information available on the the enzymatic hydrolysis of waste paper in the presence ofCO $\mathrm{C}_{2}$.

The aim of this study is to make a preliminary assessment of the paper pretreatment process and the enzymatic hydrolysis of waste HVS A4 paper in pressurized $\mathrm{CO}_{2}$. To gain better insights on the process, the microcrystalline cellulose (MCC) and HVS A4 paper were first used in the experiments as model compound.In this paper, we report experimental results on the enzymatic hydrolysis of MCC and HVS A4 paper in pressurized $\mathrm{CO}_{2}$. The obtained results will be valuable input for future experimental works using waste HVS A4 paper.

\section{Methods}

\subsection{Material}

Microcrystalline cellulose (MCC) was purchased from Merck (Germany). HVS paper A4 (70 GSM)was obtained from of E-Paper (Indonesia). The cellulase enzyme (Trichodermareesei) was purchased from Sigma Aldrich. Analytical grade sodium acetate $\left(\mathrm{NaCH}_{3} \mathrm{COO}\right)$ buffer solution, sodium hydroxide $(\mathrm{NaOH})$, acetic acid $\left(\mathrm{CH}_{3} \mathrm{COOH}\right)$, and sulfuric acid $\left(\mathrm{H}_{2} \mathrm{SO}_{4}\right)$ and various reducing sugar (glucose, cellobiose, xylose, maltose, and arabinose)were purchased from Sigma Aldrich. All chemicals were used as received without further purification. High purity $\mathrm{CO}_{2}(\geq 98 \%$ volume $)$ and $\mathrm{N}_{2}(\geq 98 \%$ volume) were purchased from Sangkuriang (Indonesia).

\subsection{Experimental Procedures}

Both pretreatment and enzymatic hydrolysis processes were performed in a highpressure vessel equipped with a controlled heating system and a high pressure pump (Chrom Tech) with an integrated cooling system. The detailed experimental procedures are described below.

\subsubsection{Pretreatment Process}

A series of experiments were performed with a pressure of $80-100$ bar, at a constant temperature of $75^{\circ} \mathrm{C}$ and reaction time of 90 minutes in order to determine the optimum conditions of pre-treatment using pressurized $\mathrm{CO}_{2}$. The sample (1-2 g) was put into the reactor and then the reactor was flused by $\mathrm{N}_{2}$ for approximately 1-2 minutes to remove $\mathrm{O}_{2}$ from the reactor. Subsequently, the reactor was pressurized by $\mathrm{CO}_{2}$ until 50 bar, and then the heater was turned on to reach the tempertaure set point $\left(75^{\circ} \mathrm{C}\right)$. Whenever necessary, $\mathrm{CO}_{2}$ was then addedto reach the desired pressure.After 90 minutes (Kerton, F.M), the temperature and pressure of the reactor were reduced to the room condition. Each result from the pre-treatment process was then hydrolyzed in pressurized $\mathrm{CO}_{2}$ with an enzyme intake of $1 \%(\mathrm{v} / \mathrm{v})$, under the conditions of 100 bar and $50^{\circ} \mathrm{C}$ for 90 minutes. The products were analyzed using HPLC, XRD and SEM.

\subsubsection{Hydrolysis Process}

Enzymatic hydrolysis process in pressurized $\mathrm{CO}_{2}$ was performed using samples that previously pretreatedbased on the optimum condition as described earlier (see above). In the enzymatic hydrolysis process, the experiments were done with a pressure of 100, 125and 150 bar, cellulaseintake of $1 \% \mathrm{v} / \mathrm{v}, 3 \% \mathrm{v} / \mathrm{v}$ and $5 \% \mathrm{v} / \mathrm{v}$ and a fixed temperature of $50{ }^{\circ} \mathrm{C}$.Sodium acetate buffer $(20 \mathrm{ml}, 0.05 \mathrm{M})$ was added into the reactor. After the reaction ( 90 minutes), the sample was filtered and followed by the addition of $\mathrm{NaOH}(1 \mathrm{ml}, 0.5 \mathrm{M})$ for enzyme inactivation. The samples were then quantified using HPLC.

\subsection{Analytical Equipment}

High Pressure Liquid Chromatograph (HPLC) were aquired using a Hitachi HPLC with a Aminex HPX-87P collumn. The morphology of the products were determined using Scanning ElectronMicroscopeon JEOL T330A. The crystallinity of the sampleswereanalyzed using a Philips Analytical X-Ray Diffractometry (XRD). 


\section{Results and Discussion}

\subsection{Pretreatment of HVS A4 Paper and MCC with Pressurized $\mathrm{CO}_{2}$}

Pretreatment was performed on $\mathrm{MCC}$ and paper sample using pressurized $\mathrm{CO}_{2}$. The paper's size was reduced using blender to increase the contact area. The pretreatment processes didn't change MCC's colors but there was a slightly change on the paper's color (white to yellowish). The best pretreatment condition for both MCC and HVS A4 paper (based on the maximum glucose concentration) was obtained at pressure of 80 bar and temperature of $75^{\circ} \mathrm{C}$.

SEM was performed to find out the effect of pretreatment on the morphological changes of the HVS A4 paper and MCC.It can be seen in Figure 1(b) that the MCC crystalline structure become thinnerand more tenuous compared to Figure 1(a)implying that the structure is easier to be penetrated by the enzyme after the pretreatment process. The same results existed in the HVS A4 paper after pretreatment (Figure 2a and b). The pretreated paper sample(Figure 2b) have more hole in their structure and the cellulose fiber become thinner as compared with the untreated one (Figure 2a).
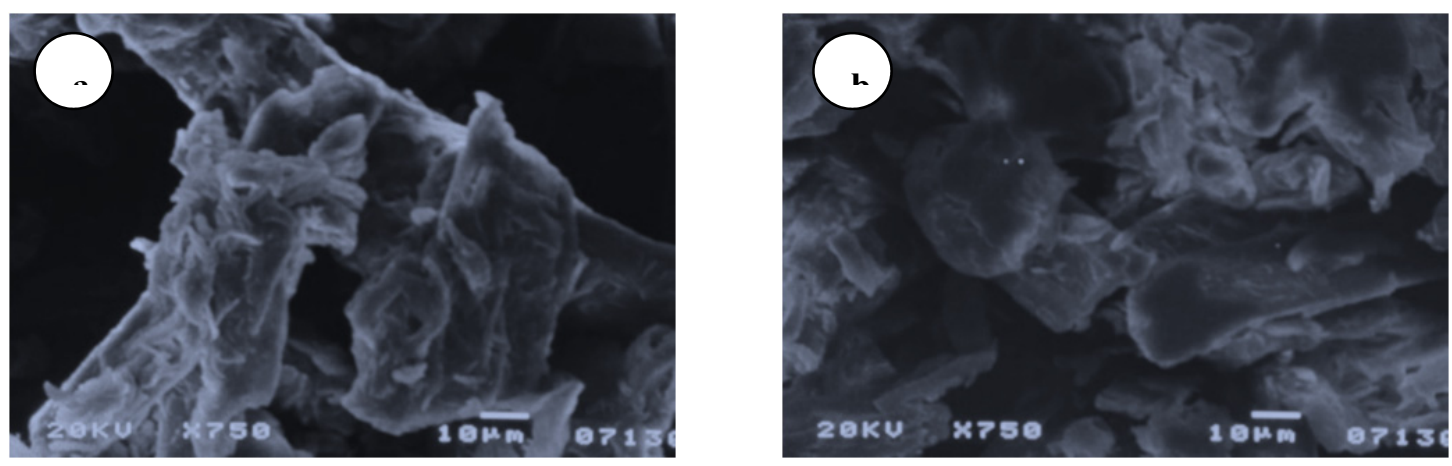

Figure 1. SEM analysis for (a) untreated MCC; (b) pretreated MCC at pressure of $80 \mathrm{bar}$ and temperature of $75^{\circ} \mathrm{C}$
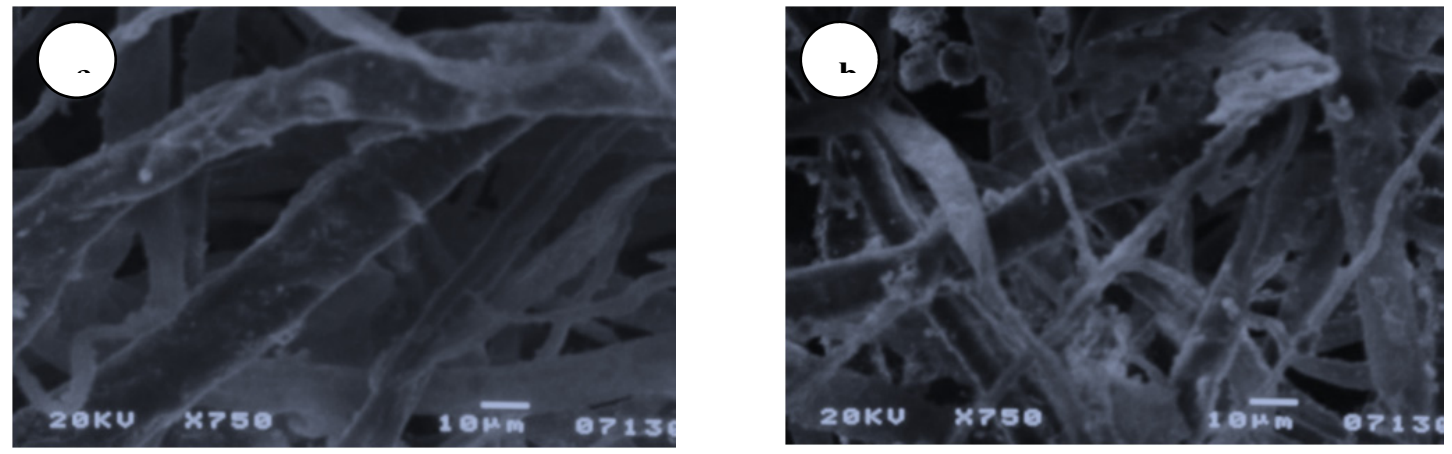

Figure 2. SEM analysis for (a) untreated paper; (b) pretreated paper at pressure of 80 bar and temperature of $75^{\circ} \mathrm{C}$

In addition, XRD was also performed to determine the difference in crystalline structure and degree of crystallinity between untreated sample and pretreated sample. XRD analysis was performed to both untreated MCC and paper sample, also to both pretreated MCC and paper sample. The pretreatment process was performed under the conditions of $80 \mathrm{bar}$ and $75^{\circ} \mathrm{C}$. XRD analysis was performed from $5^{\circ}$ irradiation angle until $64,82^{\circ}$ with beaming range $0,02^{\circ}$ every beams. Figure 3 shows that paper and MCC have similiarities in crystalline structure after theywere analyzed using XRD. 

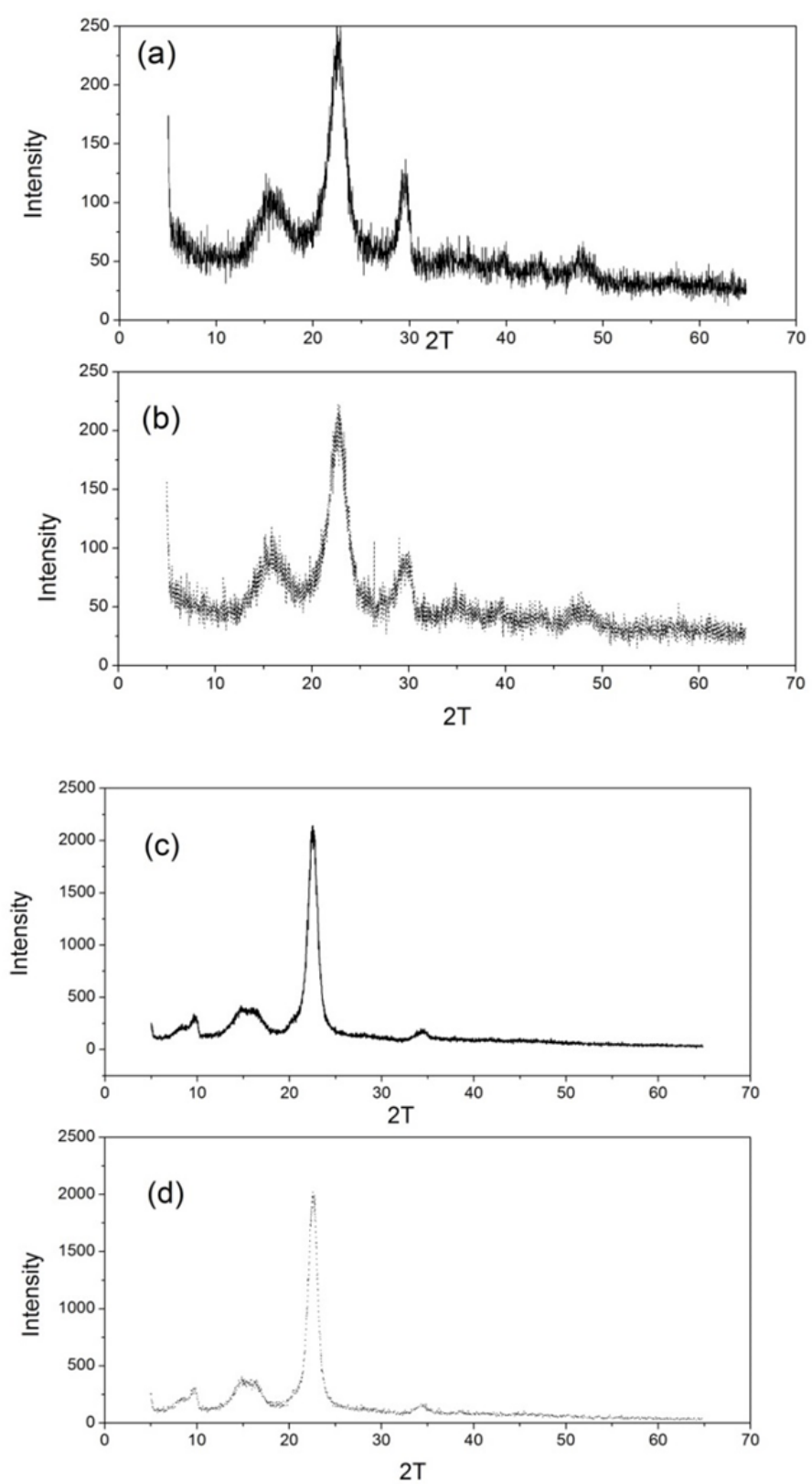

Figure 3. XRD pattern of untreated (a) and pretreated HVS A4 paper (b) and untreated MMC (c) and pretreated $\mathrm{MCC}(\mathrm{d})$

The data obtained from this analysis was then processed using Origin v.9.1 programsto determine the degree of crystallinity from the samples based on following equation (Raghavendra, R Hedge).Table 1 and 2 gives the peaks area of MCC and HVS A4 paper, respectively.

$$
X c=\frac{\text { Crystalline phase area }(A c)}{\text { crystalline phase area }+ \text { amorphous phase area }(A t)}
$$


Table 1. The results of XRD analysis for MCC

\begin{tabular}{ccccccc}
\hline \multirow{2}{*}{ Peak } & \multicolumn{3}{c}{ Before Pretreatment } & \multicolumn{3}{c}{ After Pretreatment } \\
\cline { 2 - 7 } & $2 \Theta$ & I & Area & $2 \Theta$ & I & Area \\
\hline 1 & 9.62 & 228.117 & 322.2017 & 9.76 & 196.4257 & 316.9167 \\
2 & 14.74 & 268.724 & 762.8840 & 14.86 & 281.7159 & 702.654 \\
3 & 22.52 & 1977.178 & 2831.8736 & 22.54 & 1877.9395 & 2658.476 \\
4 & 34.22 & 99.054 & 109.36833 & 34.8 & 101.5937 & 144.9503 \\
\hline & Total Crystalline & 4026.32787 & Total Crystalline & 3822.997 \\
& Total Amorphous & 1429.401 & Total Amorphous & 1561.5058 \\
\hline \multicolumn{4}{c}{ Degree of } & 0.738 & Degree of & 0.71 \\
\multicolumn{4}{c}{ crystallinity } & \multicolumn{5}{c}{ crystallinity } \\
\hline
\end{tabular}

From Table1 it can be seen thatthere isa decrease inthe peakheightofthe pretreated sample. The peak reduction cause area reduction from the crystalline areaso the degree of crystallinity is also decreased. Degree of crystallinity (Xc) of untreated MCCis 0.738 and for pretreated sample the result given is 0.71 . There is a slight decrease inMCC degree of crystalinity after pretreated. The same trend is observed in the HVS A4 paper results (Table 2), the degree of crystallinity decrease from 0.722 to 0.712 after pretreatment process. The decrease in degree of crystallinity implythat the pretreatment using pressurized $\mathrm{CO}_{2}$ to both HVS A4 paper and MCC reduce the internal mass transfer limitation (due to an increase in the amorphous phase, see Table 1 and Table 2). Therefore, after the pretreatment, the hidrolysis reaction rate increases and lead to a higher amount of glucose as the desired product (Santos, A. L. F).

Table 2. The result of XRD analysis for HVS A4 paper

\begin{tabular}{ccccccc}
\hline Peak & \multicolumn{3}{c}{ Before Pretreatment } & \multicolumn{3}{c}{ After Pretreatment } \\
\cline { 2 - 7 } & $2 \Theta$ & I & Area & $2 \Theta$ & I & Area \\
\hline 1 & 15.44 & 121 & 15.101 & 15.44 & 119 & 146.039 \\
2 & 22.46 & 266 & 359.477 & 22.46 & 222 & 347.088 \\
3 & 29.58 & 137 & 106.622 & 29.58 & 110 & 90.4236 \\
& Total Crystalline & 623.2 & Total Crsytalline & 583.56 \\
& Total Amorphous & 239.99 & Total Amorphous & 236.1898 \\
& Degree of crystallinity & 0.722 & Degree of crystallinity & 0.712 \\
\hline
\end{tabular}

\subsection{Hydrolysis of MCC and HVS A4 Paper with Pressurized $\mathrm{CO}_{2}$}

Hydrolysis process was performed at temperature of $50^{\circ} \mathrm{C}$ with pressure variation of 100,125 and 150 bar and with an enzmye intake of 1,3 , and $5 \%(\mathrm{v} / \mathrm{v})$. Table 3 shows the glucose concentration produced from MCC and HVS A4 paper. It is clear that a maximum glucose concentration in most cases is obtained with an enzyme intake of 3\% for both MCC and HVS A4 paper. The trend may be related to the higher reactivity at a higher enzyme intake, as expected, however, the reactivity decrease at higher enzyme intake due to the lower solublity of the enzyme in $\mathrm{CO}_{2}$. The latter lead to an increase of the internal diffusion limitation. 
Table 3. Glucose concentration of MCC hydrolysis (ppm)

\begin{tabular}{|c|c|c|c|c|}
\hline \multirow[t]{2}{*}{$\mathrm{MCC}$} & & \multicolumn{3}{|l|}{$\mathrm{P}$ (bar) } \\
\hline & & 100 & 125 & 150 \\
\hline \multirow[t]{3}{*}{ Enzyme (\%v/v) } & $1 \%$ & 6150,235 & 6447,525 & 2898,665 \\
\hline & $3 \%$ & 6745,41 & 6992,16 & 7265,58 \\
\hline & $5 \%$ & 7602,35 & 3919,405 & 6455,82 \\
\hline \multirow[t]{2}{*}{ HVS A4 Paper } & & $\mathrm{P}$ (bar) & & \\
\hline & & 100 & 125 & 150 \\
\hline \multirow[t]{3}{*}{ Enzyme $(\% \mathrm{v} / \mathrm{v})$} & $1 \%$ & 1449,74 & 3557,14 & 942,907 \\
\hline & $3 \%$ & 3588,84 & 3560,44 & 4560,79 \\
\hline & $5 \%$ & 1693,36 & 2770,04 & 1327,95 \\
\hline
\end{tabular}

Similar trend is also observed in the pressure effect. For most cases, a maximum glucose concentration is obtained at 125 bar (Table 3) which is in agreement with the one reported in literature (Park C.Y). The results may be related to the interplay between plasticizing effect of cellulose matrices at higher pressure which lead to a higher reactivity and also the compressive effect at higher pressure resulting with a decrease in the reactivity. This complex and peculiar behavior may influence the overall reactivity of the process.

Another important remarks is that glucose concentration obtained form MCC hydrolysis is somewhat higher compared with the one from HVS A4 paper. This imply that the enzymatic hydrolysis of HVS A4 paper has a lower reactivity which may be related to the more complex structure of HVS A4 compared with MCC.

\subsection{Assesment for Fermentation Process}

Hydrolysis process which has been carried out will be followed by the fermentation process of glucose to bioethanol using Saccharomyces cereviceae. However, to be converted into bioethanol, the hydrolysate must contain high purity of glucose and no impurities such as organic acids and HMF which can inhibit the fermentation process (Berta Sanchez, J. B). After quantitative and qualitative analysis was performed, it is known that there are no organic acids (such as levulinic acid), furfural and hydroxymethyl furfural (HMF) produced from MCC and paper's hydrolysis. This means that the products obtained from MCC and paper hydrolysis using this method are safe to be used in fermentation process.

An optimum glucose amount for the synthesized of bioethanol by fermentation process is about $80-160 \mathrm{~kg} / \mathrm{m}^{3}$ or about 80.000-160.000 ppm glucose without any impurities or inhibitors such as HMF. The rate of ethanol production on that glucose amount was between $100-120 \mathrm{~g}$ ethanol $/ \mathrm{kg}$ glucose.hr at temperature of $30^{\circ} \mathrm{C}$ (Yan Lin, W.Z).The glucose obtained from the hydrolysis of MCC was ina range of $2898.665 \mathrm{ppm}$ to $7602.35 \mathrm{ppm}$ with the highest yield of $16.725 \%(\mathrm{w} / \mathrm{w})$ of the mass of the MCC used. The hydrolysis of HVS A4 paper resulting with a lower amount of glucose (942.907-4560.79 ppm) compared with the glucose obtained from MCC.Both results imply that further optimization of the hydrolysis in pressurized $\mathrm{CO}_{2}$ are necessary to improve the amount of glucose produced from the process. 


\section{Conclusions}

In this work, a series of experiments were done in order to investigate the potential used of pressurized $\mathrm{CO}_{2}$ in the pretreatment and enzymatic hydrolysis of MCC and HVS A4 paper to produce glucose as a precursor for bioethanol production. The pretreatment process using pressurized $\mathrm{CO}_{2}$ produces finer and thinner fibers of MCC and HVS A4 paper. Furthermore, reformations of the crystal shape, and a slightly decline in crystallinity are observed from the experiment.

A maximum result for MCC (glucose concentration of $7602.35 \mathrm{ppm}$ ) is obtained while the experiment was performed under the conditions of 80 bar and $75^{\circ} \mathrm{C}$ for pretreatment and hydrolysis at pressure of $100 \mathrm{bar}$, and temperature of $50^{\circ} \mathrm{C}$ with $5 \%$ of cellulase intake. Meanwhile for HVS paper, an optimum result (glucose concentration of $4560.79 \mathrm{ppm}$ ) is obtained under the conditions of $80 \mathrm{bar}$ and $75^{\circ} \mathrm{C}$ for pretreatment and hydrolysis at $150 \mathrm{bar}, 50^{\circ} \mathrm{C}$ with $3 \%$ of cellulase intake. In addition, this study shows thatthe productcan be further used in the fermentation step and this open a new perspective on the application of pressurized $\mathrm{CO}_{2}$ as the solvent the enzymatic processes.

\section{Acknowledgements}

The authors thanks the University Catholic Parahyangan for providing a research fund with an Internal Research Scheme (contract no III/LPPM/2013-03-09-P).

\section{References}

Alinia, R., Zabihi, S., Esmaeilzadeh, F., \& Kalajahi, J. F. (2010). Pretreatment of wheat straw by supercritical $\mathrm{CO}_{2}$ and its enzymatic hydrolysis for sugar production. Biosystems Engineering, 107. http://dx.doi.org/10.1016/j.biosystemseng.2010.07.002

Ana Luiza Ferreira Santos, K. Y. F. K., \& Gerson Luiz Vieira Coelho. (2011). Enzymatic saccharification of lignocellulosic materials after treatment with supercritical carbon dioxide. The Journal of Supercritical Fluids, 56(2011), 277-282. http://dx.doi.org/10.1016/j.supflu.2010.10.044

Anjani, A. (2011). Houshold Waste Management in Indonesia. Master, Tohoku.

Berta Sanchez, J. B. (2014). Effects of furfural and 5-hydroxymethylfurfural on the fermentation of Saccharomyces cerevisiae and biomass production from Candida guilliermondii.Enzyme and Microbial Technology, 10(5).

BPS (2012). Statistik Indonesia 2012. Badan Pusat StatistikIndonesia.

Franceschin, G., Favaron, C., \& Bertucco, A. (2010). Waste Paper as Carbohydrate Source for Biofuel Production: An Experimental Investigation. Chemical Engineering Transaction, 20.

Howard, R. L., et al. (2003). Lignocellulose Biotechnology: Issues of Bioconversion and Enzyme Production.African Journal of Biotechnology, 2. http://dx.doi.org/10.5897/AJB2003.000-1115

Kerton, F. M. (2010). Green Chemical Technologie. In J. H. Clark \& F. E. I. Deswarte (Eds.), Introduction to Chemicals from Biomass. John Wiley \& Sons, Ltd..

M. Wang, J. W., \& Tan, J. X. (2011). Lignocellulosic Bioethanol: Status and Prospects. Taylor \& Francis Group. http://dx.doi.org/10.1080/15567030903226249

Muratov, G., \& Kim, C. (2002). Enzymatic hydrolysis of cotton fibers in supercritical $\mathrm{CO}_{2}$.Biotechnology and Bioprocess Engineering, 7. http://dx.doi.org/10.1007/BF02935884

Narayanaswamy, N., Faik, A., Goetz, D. J., \& Gu, T. (2011). Supercritical carbon dioxide pretreatment of corn stover and switchgrass for lignocellulosic ethanol production. Bioresource Technology, 102. http://dx.doi.org/10.1016/j.biortech.2011.04.052

Park, C. Y., Ryu, Y. W., \& Kim, C. (2001). Kinetics and Rate of Enzymatic Hydrolysis of Cellulose in Supercritical Carbon Dioxide.Korean J. Chem. Eng., 18(4). http://dx.doi.org/10.1007/bf02698293

Raghavendra, R., Hedge, M. G. K., \& Atul, D. (2014). Polymer Crystallinity. Retrieved July 20, 2014, from http://www.engr.utk.edu/mse/Textiles/Polymer\%20Crystallinity.htm

Santos, A. L. F., Kawase, K. Y. F., \& Coelho, G. L. V. (2011). Enzymatic saccharification of lignocellulosic materials after treatment with supercritical carbon dioxide.The Journal of Supercritical Fluids, 56. http://dx.doi.org/10.1016/j.supflu.2010.10.044

Srinivasan, N., \& Ju, L. K. (2010). Pretreatment of guayule biomass using supercritical carbon dioxide-based method.Bioresource Technology, 101. http://dx.doi.org/10.1016/j.biortech.2010.07.069 
Sutjiadi, H. A., Hardosubroto, H., \& Girisuta, B. (2010). Optimisasi Proses Hidrolisis Kertas Bekas dengan Menggunakan Metode Hidrolisis Termal. in Seminar Nasional Teknik Kimia “Kejuangan”: Yogyakarta.

Taherzadeh, M. J., \& Karimi, K. (2008). Pretreatment of Lignocellulosic Wastes to Improve Ethanol and Biogas Production: A Review.International Journal of Molecular Sciences, 9. http://dx.doi.org/10.3390/ijms9091621

Yan, Lin, W. Z., Chunjie, L., Kei, S., Shuzo, T., \& Hainan, K. (2012). Factors affecting ethanol fermentation using Saccharomyces cerevisiae BY4742. Biomass \& Bioenergy.

\section{Copyrights}

Copyright for this article is retained by the author(s), with first publication rights granted to the journal.

This is an open-access article distributed under the terms and conditions of the Creative Commons Attribution license (http://creativecommons.org/licenses/by/3.0/). 